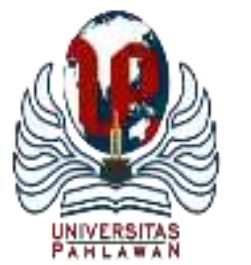

Edukatif : Jurnal Ilmu Pendidikan Volume 4 Nomor 1 Tahun 2022 Halm 170 - 175

EDUKATIF: JURNAL ILMU PENDIDIKAN

Research \& Learning in Education

https://edukatif.org/index.php/edukatif/index

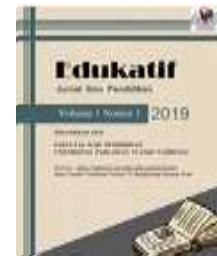

\title{
Optimalisasi Pemanfaatan Akun Pembelajaran untuk Kegiatan Pembelajaran Daring
}

\author{
Budi Tri Cahyono ${ }^{1 凶}$, Wahyu Nugroho ${ }^{2}$ \\ Universitas Sebelas Maret, Indonesia ${ }^{1}$, \\ BP PAUD dan DIKMAS Jawa Timur, Indonesia ${ }^{2}$ \\ E-mail : $\underline{\text { buditricahyono@staff.uns.ac.id }}^{1}, \underline{\text { cakwahyukumis@ gmail.com }}^{2}$
}

\begin{abstract}
Abstrak
Pembelajaran di sekolah yang dilakukan selama ini adalah pembelajaran tatap muka (luring) dimana siswa dan guru saling berinteraksi secara langsung tanpa adanya sekat/pemisah. Ketika wabah Covid-19 melanda Indonesia awal April 2020, pembelajaran luring terhenti beberapa bulan, yang menyebabkan guru mencari alternatif untuk melakukan pembelajaran daring. Penelitian ini akan mencoba melihat proses pembelajaran daring, serta kendala yang dihadapi masing-masing guru dan siswa dalam pelaksanaan pembelajaran daring. Penelitian ini menggunakan pendekatan kualitatif dengan metode deskriptif. Teknik pengambilan data dalam penelitian ini dengan observasi dan wawancara, sumber datanya adalah guru dan siswa Sekolah Dasar kelas V dan VI. Hasil proses pembelajaran daring dilaksanakan dirumah dengan menggunakan aplikasi Google Classroom, Google Meet dan Google Drive. Hasil penelitian ini menyebutkan bahwa dengan memanfaatkan akun pembelajaran belajar.id guru dan siswa dapat mengoptimalkan pembelajaran daring di masa pandemi Covid-19. Penelitian ini memberikan kontribusi bagi sekolah dasar dengan menggunakan akun pembelajaran belajar.id merupakan salah satu alternatif pilihan pembelajaran daring yang di fasilitasi Kementerian Pendidikan, Kebudayaan, Riset dan Teknologi melalui Direktorat Jenderal Guru dan Tenaga Kependidikan bekerjasama dengan Refo Indonesia.
\end{abstract}

Kata Kunci: akun pembelajaran, pembelajaran daring

\begin{abstract}
Learning in schools that has been carried out so far is face-to-face learning (offline) where students and teachers interact directly with each other without any dividers/separators. When the COVID-19 outbreak hit Indonesia in early April 2019, offline learning was suspended for several months, which caused teachers to look for alternatives to online learning. This study will try to look at the online learning process, as well as the obstacles faced by each teacher and student in the implementation of online learning. This study uses a qualitative approach with a descriptive method. The data collection technique in this study was observation and interviews, the data sources were teachers and elementary school students in grades V and VI. The results of the online learning process are carried out at home using the Google Classroom, Google Meet and Google Drive applications. The results of this study state that by using the learning account on learning.id, teachers and students can optimize online learning during the COVID-19 pandemic. This research contributes to Elementary Schools using the learning account Belajar.id, which is an alternative online learning option facilitated by the Ministry of Education, Culture, Research and Technology through the Directorate General of Teachers and Education Personnel in collaboration with Refo Indonesia.
\end{abstract}

Keywords: learning account, online learning

Copyright (c) 2022 Budi Tri Cahyono, Wahyu Nugroho

$\triangle$ Corresponding author

Email : buditricahyono@staff.uns.ac.id

DOI : https://doi.org/10.31004/edukatif.v4i1.1766

ISSN 2656-8063 (Media Cetak)

ISSN 2656-8071 (Media Online)

Edukatif : Jurnal Ilmu Pendidikan Vol 4 No 1 Tahun 2022 p-ISSN 2656-8063 e-ISSN 2656-8071 


\section{PENDAHULUAN}

Penyebaran pandemi corona virus disease 19 (Covid-19) telah memberikan tantangan tersendiri bagi semua sisi kehidupan khususnya bagi pendidikan di Indonesia. Kebijakan social distancing atau tetap dirumah saja dan physical distancing atau menjaga jarak jika dilihat dari dua sudut pandang, disisi pertama akan memberikan efek positif (Ali, 2020), hingga "Pemberlakuan Pembatasan Kegiatan Masyarakat Darurat Corona Virus Disease 2019 Di Jawa Timur"(Gubernur Jawa Timur, 2021). Kondisi ini mengharuskan masyarakat untuk tetap diam di rumah, belajar, bekerja, dan beribadah di rumah. Akibat dari kebijakan tersebut membuat sektor pendidikan seperti sekolah maupun perguruan tinggi menghentikan proses pembelajaran secara tatap muka. Sebagai gantinya, proses pembelajaran dilaksanakan secara daring yang bisa dilaksanakan dari rumah masing-masing siswa (Arora, Amit Kumar, 2020). Belajar merupakan kegiatan bagi setiap orang, pengetahuan, keterampilan, kebiasaan, kegemaran dan sikap seseorang terbentuk di modifikasi dan berkembang disebabkan belajar" (Sardiman, 2007). Oleh karena itu pembelajaran harus tetap berlangsung di tengah Covid-19 demi mencerdaskan anak bangsa Indonesia secara berkelanjutan. Sesuai dengan Surat Edaran Mendikbud Nomor 4 tahun 2020 tentang pelaksanaan kebijakan pendidikan dalam masa darurat penyebaran corona virus disease (Covid-19) menganjurkan untuk melaksanakan proses belajar dari rumah melalui pembelajaran daring. Kesiapan dari pihak penyedia layanan maupun siswa merupakan tuntutan dari pelaksanaan pembelajaran daring. Pembelajaran daring (online) secara umum adalah suatu pembelajaran yang dilakukan secara elektronik dengan menggunakan media berbasis komputer serta sebuah jaringan. Belajar online dikenal juga dengan istilah pembelajaran elektronik, e-learning, on-line learning, internet-enabled learning, virtual learning, atau web-based learning (kanal.web.id, 2015). Pelaksanaan pembelajaran daring ini memerlukan perangkat pendukung seperti komputer atau laptop, gawai, dan alat bantu lain sebagai perantara yang tentu saja harus terhubung dengan koneksi internet. Hal ini sependapat dengan yang diumgkapkan oleh (Dewi, 2020) pembelajaran daring ialah proses pembelajaran yang memanfaatkan jaringan internet. Pada proses pembelajaran ini peserta didik dapat memiliki keleluasaan dalam belajar karena bisa dilakukan dimana saja. Dengan pelaksanaan pembelajaran dari rumah secara daring, guru dituntut untuk lebih inovatif dalam menyusun langkah-langkah pembelajaran. Perubahan cara mengajar ini tentunya membuat guru dan siswa beradaptasi dari pembelajaran secara tatap muka di kelas menjadi pembelajaran daring (Mastuti, Rini, 2020).

Kegiatan pembelajaran yang dilakukan secara daring dari rumah (Ramanta, Widayanti, 2020), menyebabkan aktivititas pembelajaran yang biasanya dilakukan secara tatap muka, mengalami kendala sehingga tidak bisa maksimal. Kendala utama yang dihadapi anak adalah pendampingan orang tua yang kurang memahami literasi digital serta motivasi anak yang kurang. Seluruh sistem sekolah hendaknya familiar dengan teknologi yang memungkinkan siswa belajar lebih cepat, lebih baik, dan juga lebih pintar. Teknologi merupakan kunci untuk model sekolah masa depan yang lebih baik. Oleh karena itu seluruh pendidik di Indonesia dalam hal menyampaikan proses pendidikan dengan diharuskan menggunakan teknologi terkini (Lestari, 2020). Umumnya siswa yang berada dikelas tinggi sudah lebih mengerti materi yang disampaikan oleh guru, sedangkan siswa kelas rendah masih membutuhkan pengawasan dan bimbingan yang ekstra dalam memahami dan mengerjakan tugas yang diberikan. Dalam hal ini, peran orang tua diharapkan dapat membantu pendidik dalam mendampingi anak pada proses pembelajaran daring dirumah. Dalam hal ini dibutuhkan kemampuan literasi digital dari guru untuk menumbuhkan kesiapan anak dalam proses pembelajaran daring. Berdasarkan latar belakang masalah diatas penulis berkeinginan untuk melakukan penelitian dengan judul "Optimalisasi Pemanfaatan Akun Pembelajaran Untuk Kegiatan Pembelajaran Daring". Seringkali masalah kuota jaringan yang digunakan untuk pembelajaran secara daring menjadi kendala, untuk itu sesuai peraturan Sesjen Kemdikbud-Ristek nomor 17 tahun 2021 tentang perubahan kedua atas peraturan Sesjen Kemendikbud nomor 4 tahun 2021 tentang petunjuk teknis penyaluran bantuan 
pemerintah paket kuota data internet tahun 2021, maka tidak ada alasan untuk pembelajaran daring terjadi kendala.

Secara nyata keberhasilan dari pemanfaatan akun pembelajaran ini sudah dibuktikan oleh pendidik dan tenaga kependidikan di masing-masing satuan pendidikan untuk pembelajaran daring, dimana materi-materi / bahan-bahan ajar telah simpan di google drive.

\section{METODE PENELITIAN}

Penelitian ini menggunakan pendekatan analisis kualitatif yang berkenaan dengan Optimalisasi Pemanfaatan Akun Pembelajaran Untuk Kegiatan Pembelajaran Daring dengan menggunakan akun pembelajaran belajar id antara guru dan siswa, peneliti melakukan hipotesis atau membuat suatu generalisasi dari eksplorasi dan memusatkan pada fokus masalah yang diteliti dengan menggunakan sumber data dari penelitian ini. Data-data yang dibutuhkan juga diambil dalam situasi lapangan yang bersifat alami tanpa dimanipulasi, diatur dengan eksperimen maupun tes.

Teknik pengambilan data menggunakan observasi dan wawancara, sumber datanya adalah guru yang telah mengaktifkan akun pembelajaran belajar.id serta siswa yang telah mengaktifkan akun pembelajaran belajar.id di Sekolah Dasar di Kecamatan Ngawi Kabupaten Ngawi. Sementara analisis datanya menggunakan analisis data model interaktif dengan menyajikan data, reduksi data, membuat kesimpulan, dan terakhir melakukan verifikasi data, penelitian ini berlangsung selama tiga bulan yaitu dari Juni s.d. Agustus di Kecamatan Ngawi Kabupaten Ngawi.

\section{HASIL DAN PEMBAHASAN}

Hasil pengamatan dan wawancara yang peneliti lakukan pada guru-guru dan siswa yang telah mengaktifkan belajar id untuk melaksanakan pembelajaran daring. Kementerian Pendidikan dan Kebudayaan melalui Direktorat Jenderal Guru dan Tenaga Kependidikan telah menerbitkan Peraturan nomor 18 Tahun 2020 Tentang Petunjuk Teknis Pemanfataan Data Pokok Pendidik untuk Akun Akses Layanan Pembelajaran, Peraturan nomor 16 Tahun 2021 tentang Petunjuk Teknis Pemanfataan Data Pokok Pendidikan Untuk Akses Layanan Pembelajaran telah memberikan akses gratis kepada guru- guru dan siswa yang telah terdaftar di dapodik. Akun pembelajaran belajar id ditujukan untuk mendukung proses pembelajaran di satuan Pendidikan melalui penerapan teknologi serta meningkatkan keterhubungan antara layanan pembelajaran. Penamaan user id yang unik bagi masing-masing individu sasaran yaitu untuk pendidik menggunakan namakun@guru.sd.belajar.id untuk tenaga kependidikan menggunakan namaakun@admin.sd.belajar.id untuk peserta didik menggunakan namaakun@sd.belajar.id pemilahan user id ini untuk memudahkan admin utama Pusat data dan Teknologi Informasi Kementerian Pendidikan, Kebudayaan, Riset dan Teknologi untuk memetakan. Pertama-tama akun pembelajaran ini dengan mengolah nama individu, nomer induk siswa nasional (NISN), serta nomer induk kependudukan (NIK) dari Dapodik untuk menentukan nama akun (user ID), menentukan akses masuk akun (password) untuk setiap individu sasaran, pembuatan akun pembelajaran melibatkan penyelenggara layanan berbasis elektronik atau mitra resmi yang ditunjuk oleh penyelenggara.

Pendistribusian akun pembelajaran yang telah jadi dilakukan oleh Pusat data dan Teknologi Informasi Kementerian Pendidikan, Kebudayaan, Riset dan Teknologi melalui link http://pd.data.kemdikbud.go.id/, operator masing-masing satuan Pendidikan sekolah mengunduh melalui menu unduh akun ada 3 file berbentuk CSV yaitu Peserta Didik, PTK dan Admin. Operator satuan Pendidikan wajib mendistribusikan nama akun (user ID) dan akses masuk akun (password) kepada pengguna akun pembelajaran di satuan Pendidikan yang bersangkutan. Awal pengguna akun pembelajaran mengakses akun pembelajaran masingmasing, akan diminta untuk: a. menyetujui syarat dan ketentuan penggunaan akun pembelajaran, b. 
melakukan penggantian akses akun (password). Jika dalam pemanfaatan pembelajaran pengguna akun pembelajaran di satuan pendidikan lupa akses masuk maka operator sekolah bisa mengubah akses masuk akun. Tetapi ketika akun pembelajaran operator sekolah lupa akses masuk maka admin pusat data dan teknologi informasi yang mengubah. Pengamatan awal guru-guru mengaktifkan akun pembelajar untuk memastikan akun pembejaran yang diperoleh benar-benar aktif dan dapat digunakan, setelah memastikan akun aktif, guru-guru mencoba untuk mempelajari beberapa fitur-fitur yang ada di akun pembelajaran belajar.id di pandu oleh salah satu guru SDN Margomulyo 1 Ngawi bapak Budi Utomo, S.Pd., M.Pd yang juga sebagai Certified Trainer.

\section{Pembelajaran Daring}

Aktifasi akun pembelajaran di Kabupaten Ngawi untuk pendidik dan tenaga kependidikan 5.065 yang telah aktif $84,66 \%$, sedangkan untuk siswa jumlah akun pembelajaran pendidik dan tenaga kependidikan 16.989 yang telah aktif 76,5\%, sedangkan di Kecamatan Margomulyo Kabupaten Ngawi ada 31 Sekolah Dasar Negeri dan semua pendidik dan tenaga kependidikannya telah mengaktifkan akun pembelajaran, sedangkan untuk siswanya dari total 4.300 yang sudah mengaktifkan akun pembelajaran baru 29,82\% yaitu sejumlah 1.292 (data 01-12-2021 pukul 15.38 Wib). Setiap sekolah menugaskankan 2 guru dan 1 operator sekolah untuk mengikuti kegiatan dimaksud melalui google meet dimana maksimal yang bisa bergabung 100 user, untuk mempersiapkan guru selain dari Kecamatan Margomulyo penulis juga mempersiapkan channel youtube untuk mengakomodir jika yang bergabung melebihi dari 100 user. Pelaksanaan kegiatan pembelajaran daring dilaksanakan selama 3 hari, setiap sesinya waktu yang digunakan 120 menit dan penugasan selama 7 hari. Hari pertama penjelasan awal yaitu pengenalan akun pembelajaran workspace for education dan cara mengelola materi pembelajaran menggunakan google drive serta bagaimana men sharing materi kepada siswa. Hari ke dua menjelaskan tentang pemanfaatan google classroom. Mengapa menggunakan google classroom disamping gratis karena sudah difasilitasi oleh Kementerian Pendidikan, Kebudayaan Riset dan Teknologi juga fitur-fitur lengkap, mudah digunakan serta bisa diakses dari berbagai perangkat. Hari ke tiga penggunaan google meet sebagai sarana untuk pembelajaran kelas maya yang dilengkapi beberapa fitur yaitu rise hand dan merekam kegiatan selama kelas maya berlangsung. Pembelajaran dengan model daring dilakukan yaitu untuk membatasi kegiatan yang dilakukan sehinggar tidak terjadi kerumunan, pembelajaran ini dilakukan di tempat yang berbeda tanpa ada tatap muka, poin utama pembelajaran tidak terikat tempat yang ditentukan.

Setiap guru wajib memiliki pemahaman literasi digital dimulai dari merancang model pembelajaran kemudian menyusun materi, meng upload di google classroom menyajikan materi di google meet. Diawal perkenalan akun pembelajaran, guru membuat video yang di upload di youtube, link di share ke grub whatsapp kelas. Orang tua perlu mendampingi pembelajaran anak pada pembelajaran daring dimana juga harus orang tua mampu memberikan bantuan serta mengamati mata pelajaran, metode, dan faktor pendukung (Priyatna, 2013). Dimana langkah dalam mendampingi pembelajaran anak di pembelajaran daring anak yaitu memberikan bantuan dan mengamati dengan mata pelajaran yang akan dipelajari. Kontrol orang tua dalam kegiatan pembelajaran harus mengontrol dan mengetahui jadwal pelajaran anak setiap hari sehingga orang tua bisa mengkondisikan diri untuk tetap bisa mendampingi anak dalam pembelajaran daring.

\section{Peran Guru}

Keberhasilan guru dalam melakukan pembelajaran daring pada situasi pandemi Covid-19 ini adalah kemampuan guru dalam berinovasi merancang, dan meramu materi, metode pembelajaran, dan aplikasi apa yang sesuai dengan materi dan metode. Aplikasi pembelajaran digital menjadi ruang belajar baru bagi para tenaga pengajar yang menjadikan mereka lebih maksimal menguasai gaya komunikasi dan interaksi berbasis media. Kreatifitas merupakan kunci sukses dari seorang guru untuk dapat memotivasi siswanya tetap 
semangat dalam belajar secara daring (online) dan tidak menjadi beban psikis. Para tenaga pengajar tetap dalam koridor pencapaian pembelajaran berbasis tiga ranah pendidikan; yaitu kognitif, afektif dan psikomotorik, kerapkali para peserta didik dibekali dengan penugasan yang mengasah produktivitas mereka untuk tetap berkarya di masa yang berbatas ini.

Di samping itu, kesuksesan pembelajaran daring selama masa Covid-19 ini tergantung pada kedisiplinan semua pihak. Oleh karena itu, pihak sekolah di sini perlu membuat skema dengan menyusun manajemen yang baik dalam mengatur sistem pembelajaran daring. Hal ini dilakukan dengan membuat jadwal yang sistematis, terstruktur dan simpel untuk memudahkan komunikasi orang tua dengan sekolah agar putraputrinya yang belajar di rumah dapat terpantau secara efektif. Peran orang tua tidak terlepas dari keberhasilan pembelajaran daring menggunakan akun pembelajaran, orang tua perlu mendampingi dan memberikan motivasi kepada putra-putrinya karena pembelajaran dilakukan dari rumah masing-masing.

Dengan demikian, pembelajaran daring sebagai solusi yang efektif dalam pembelajaran di rumah guna memutus mata rantai penyebaran Covid-19, physical distancing (menjaga jarak aman) juga menjadi pertimbangan dipilihnya pembelajaran tersebut. Kerja sama yang baik antara guru, siswa, orang tua siswa dan pihak sekolah/madrasah menjadi faktor penentu agar pembelajaran daring lebih efektif dan efisien, kegiatan pembelajaran tercapai memenuhi target sesuai dengan waktu yang telah ditentukan. Keterkaitan dengan perencanaan, penjadwalan sehingga efisiensi lebih sumber daya secara umum lebih diminimalkan dengan hasil maksimal.

\section{KESIMPULAN}

Berdasarkan pemanfaatan akun pembelajaran belajar.id dalam penerapan system pembelajaran daring hingga kebermanfaatannya menunjukkan bahwa masih diperlukan usaha ekstra dari Kementerian Pendidikan, Kebudayaan, Riset dan Teknologi dan semua pihak yang terkait agar guru dan siswa dapat melaksanakan pembelajaran daring secara efektif dan efisien. Guru-guru perlu dibekali agar terbiasa menggunakan teknologi dalam proses pembelajaran daring. Pelaksanaan pelatihan yang secara kontinyu, supaya guru-guru terbiasa menggunakan akun pembelajaran dan pemberdayaan guru-guru dalam melatih siswa didiknya dalam pembiasaan penggunaan akun pembelajaran. Selain itu sarana dan prasarana untuk pembelajaran daring ini juga perlu mendapatkan perhatian khususnya dari Kementerian Pendidikan, Kebudayaan, Riset dan Teknologi dan semua pihak yang terkait untuk memberikan support bagi guru-guru dalam pembelajaran daring.

\section{DAFTAR PUSTAKA}

Adrian, K. (2020). Pentingnya Menerapkan Social Distancing Demi Mencegah Covid-19.

Ali, Z. (2020). Social Distancing Upaya Pencegahan Penyebaran Covid-19. Jurnal Kesehatan Holistic. Vol (1), Hal 1-9

Arora, Amit Kumar, S. (2020). The Impact Of Pandemic Covid-19 On The Teaching-Learning Process: A Study Of Higher Education Teachers. Prabandhan: Indian Journal Of Management, 13(4), 214-222.

Dewi, W. A. F. (2020). Dampak Covid-19 Terhadap Implementasi Pembelajaran Daring Di Sekolah Dasar. Jurnal Ilmu Pendidikan, 2(1), 55- 61. Https://Doi.Org/10.31004/Edukatif.V2i1.89

El-Seoud, M. S. A., Taj-Eddin, I. A., Seddiek, N., El-Khouly, M. M., \& Nosseir, A. (2009). E-Learning And Students' Motivation: A Research Study On The Effect Of E-Learning On Higher Education. Ijet, 9, 20-26.

Firman, Sari Rahayu Rahman (2020). Pembelajaran Online Di Tengah Pandemi Covid-19. Indonesian Journal Of Educational Science (Ijes), 2(2), 81-89. 
Gunawan, Suranti, N. M. Y., \& Fathoroni. (2020). Variations Of Models And Learning Platforms For Prospective Teachers During The Covid-19 Pandemi Period. Indonesian Journal Of Teacher Edukation, 1, 61-70.

Herliandry, L. D., Nurhasanah, Suban, M. E., \& Heru, K. (2020). Pembelajaran Pada Masa Pandemi Covid19. Jurnal Teknologi Pendidikan, 22(1), 65-70. Https://Doi.Org/Https://Doi.Org/10. 21009/Jtp.V22i1.15286

Instruksi Menteri Dalam Negeri Nomor 01 Tahun 2021 Tentang Pemberlakuan Pembatasan Kegiatan Untuk Pengendalian Penyebaran Corona Virus Disease 2019 (Covid-19)

Kamulyan, Mulyadi Sri. (2014). Model-Model Pembelajaran Di Sekolah Dasar. Kartasura: Muhammadiyah University Press.

Kanal Pengetahuan. (2015). Pengertian Belajar Online. Diakses Melalui Https://Www.Kanal.Web.Id/Pengertian-Belajar-Online

Lestari, Y. P. (2020). Dampak Positif Pembelajaran Online Dalam Sistem Pendidikan Indonesia Pasca Pandemi Covid-19. Adalah. Http://Journal.Uinjkt.Ac.Id/Index.Php/Adalah/Article/View/15394

Mastuti, Rini, Dkk. (2020). Teaching From Home: Dari Belajar Merdeka Menuju Merdeka Belajar. Jakarta:Yayasan Kita Menulis.

Oktavian, R., \& Aldya, R. F. (2020). Pelaksanaan Pembelajaran Daring Terintegrasi Di Era Pendidikan 4.0. Jurnal Pendidikan Dan Ilmu Pengetahuan, 20(2), 129-135. Https://Doi.Org/10.30651/Didaktis.V20i2.4763

Peraturan Sekretaris Jenderal Nomor 16 Tahun 2021 Tentang Petunjuk Teknis Pemanfataan Data Pokok Pendidikan Untuk Akses Layanan Pembelajaran

Peraturan Sekretaris Jenderal Nomor 18 Tahun 2020 Tentang Petunjuk Teknis Pemanfaatan Data Pokok Pendidikan Untuk Akun Akses Layanan Pembelajaran

Peraturan Sekretaris Jenderal Kementerian Pendidikan, Kebudayaan, Riset, Dan Teknologi Nomor 17 Tahun 2021 Tentang Perubahan Kedua Atas Peraturan Sekretaris Jenderal Kementerian Pendidikan Dan Kebudayaan Nomor 4 Tahun 2021 Tentang Petunjuk Teknis Penyaluran Bantuan Pemerintah Paket Kuota Data Internet Tahun 2021

Purwanto, A., \& Pramono, R. \& D. (2020). Studi Eksploratif Dampak Pandemi Covid-19 Terhadap Proses Pembelajaran Online Di Sekolah Dasar. Edupsycouns Journal, 2, 1-12.

Putria, H., Maula, L. H., \& Uswatun, D. A. (2020). Analisis Proses Pembelajaran Dalam Jaringan (Daring) Masa Pandemi Covid-19 Pada Guru Sekolah Dasar. Jurnal Basicedu, 4(4), 861-872. Https://Doi.Org/10.31004/Basicedu.V4i4.445

Priyatna, A. (2013). Pahami Gaya Belajar Anak! Memaksimalkan Potensi Anak Dengan Modifikasi Gaya Belajar. Jakarta: Pt. Elex Media Komputindo.

Sardiman,. (2017). Interaksi Dan Motivasi Belajar Mengajar, Jakarta : Raja Grafindo

Ramanta, D., \& Widayanti, F. D. (2020). Pembelajaran Daring Di Sekolah Menengah Kejuruan Putra Indonesia Malang Pada Masa Pandemi Covid-19. Prosiding Seminar Bimbingan Dan Konseling, 6167.

Rusman. (2012). Belajar Dan Pembelajaran Berbasis Komputer Mengembangkan Profesionalisme Guru Abad 21. Bandung: Alfabeta.

Surat Edaran Nomor 37 Tahun 2020 Tentang Akun Akses Layanan Pembelajaran Bagi Peserta Didik, Pendidik, Dan Tenaga Kependidikan

Surat Edaran Nomor 800/120/204.3/2021 Tentang Sistem Kerja Selama Masa Psbb Bagi Aparatur Sipil Negara Di Lingkungan Pemerintah Provinsi Jawa Timur 